\title{
Success Factors Affecting Internationalization Process of Large Vietnamese Companies: A Conceptual Framework*
}

\author{
Viet Quoc PHAM', Bao Khac Quoc NGUYEN², Thanh Quoc LE ${ }^{3}$
}

Received: August 01, 2020 Revised: October 05, 2020 Accepted: October 15, 2020

\begin{abstract}
Internationalization of multinational companies in the globalized context is a popular topic in the academic world and it is also a strong concern of CEO/managers. However, this topic has not been well discussed in the academic community in Vietnam that can be contextualized in the typical transition economy. This paper is designed to explore critical success factors (CSF) of internationalization of large Vietnamese companies that have contributed major revenue from the international market. Through interviews with CEO/managers of successful companies geared toward world markets, the CSFs of internationalization have been identified and categorized into groups in which each CSF has interaction with each other, and together have combined impacts on the success of internationalization. The research results provide a conceptual framework to analyze factors affecting internationalization of large Vietnamese companies. Thank to this conceptual framework, further exploratory and/or confirmatory research can be developed to locate more success factors of internationalization. In addition, some particularly critical factors of internationalization success of Vietnamese companies are found to be useful to both $\mathrm{CEO} /$ managers and policymakers. CEO/managers can benefit from the research results by concentrate their limited efforts/resources in managing these CSFs, and policymaker may design CSF-based policies to boost the internationalization of domestic companies.
\end{abstract}

Keywords: Internationalization Process, Internationalization Model, Globalization, Success Factor, Conceptual Framework

JEL Classification Code: F15, F18, F23

\section{Introduction}

The integration and globalization are inevitable trends to develop the national economy of many countries. Due to the economic crisis in 1980 s and strategic movements

\footnotetext{
${ }^{*}$ Acknowledgements:

We would like to thank Editor-in-Chief as well as the anonymous referees for their highly constructive comments. The usual disclaimer applies and the views herein are the sole responsibility of the authors.

${ }^{1}$ First Author and Corresponding Author. Dean, Graduate School, University of Finance - Marketing, Vietnam [Postal Address: 2/4 Tran Xuan Soan Street, District 7, Ho Chi Minh City, 72900, Vietnam] Email: vietpq@ufm.edu.vn

2Dean of School of Finance. University of Economics Ho Chi Minh City, 59 Nguyen Dinh Chieu Street, District 3, HCM City, Vietnam. Email: nguyenbao@ueh.edu.vn

${ }^{3}$ Lecturer. Graduate School. University of Finance - Marketing, Vietnam. Email: lehaiduong68@gmail.com

(c) Copyright: The Author(s)

This is an Open Access article distributed under the terms of the Creative Commons Attribution Non-Commercial License (https://creativecommons.org/licenses/by-nc/4.0/) which permits unrestricted non-commercial use, distribution, and reproduction in any medium, provided the original work is properly cited.
}

in the system of socialist countries, Vietnam is opening the national economy to the world and has started the renovation process of the economy since 1986. Then, as the result of economy renovation, Vietnam has joined the World Trade Organization (WTO) in 2007. Due to economy openness to the world, many Vietnamese companies of different scale have been participating in the internationalization process at different levels such as: (1) import-export of materials and products as trader; (2) joint ventures, long-term alliance with foreign partners to produce/supply products with higher local added value; (3) and importing technology transfer or joining research and development (R\&D) activities with foreign companies. Some large companies have started to open offices in overseas countries for deeper involvement in international market. In fact, companies from developing countries face many difficulties in going international as research by Sanyal et al. (2020a) showed that financial capability, management expertise, experience in international market, etc., are needed. Research on internationalization of companies in developing countries mainly focuses on SME rather than large companies (Sanyal et al., 2020a; Sanyal et al., 2020b; Ali et al., 2020). 
As the result of reviewing the current literature, there are few studies about internationalization of Vietnamese companies. Kokko and Sjöholm (2004) focused in SMEs' main challenges and degree of their internationalization using three SMEs' surveys in 1990, 1996 and 2002. The authors found that very few SMEs are directly influenced by the country's internationalization and/or direct contracts with foreign firms and/or direct exports. Another study by Thai and Chong (2008) on SMEs in Vietnam using multiple case studies discovered the main drivers of SME's internationalization. They confirmed that the major driver for a company to go international includes two factors: entrepreneurs' leadership desire and need of short-term profits. So far, internationalization of large companies in Vietnam is not discussed yet in academia and, thus, it seems to be promising to focus in this type of Vietnamese companies.

Given that there is no study on internationalization of large Vietnamese companies, therefore, could be the basis for the research question to guide this study: What are critical success factors affecting the internationalization process of large Vietnamese companies? The research will concentrate on identifying some success factors of internationalization process of large Vietnamese companies, which CEO/owner/ managers could benefit from by concentrating their limited resources on the most important success factors to be prioritized. The policymakers may benefit from this research results by designing policies based on critical success factors to support internationalization of Vietnamese companies. From the academic perspective, there are many studies on internationalization of multinational corporations (MNCs) from developed countries expanding into developing countries, but there is lack of research on the opposite direction. Therefore, this article could contribute to fill this knowledge gap.

The paper is structured as follows. After the introduction in Section 1, Section 2 presents the literature review summarizing the literature related to the internationalization process/models and key factors of success to propose the conceptual framework. Section 3 discusses the methodology, choice of methods, and data collection. Section 4 presents the research results and discussion. Finally, Section 5 offers conclusion and recommendations for managerial implication as well as further research to enrich the understanding on internationalization-related topics.

\section{Literature Review}

\subsection{Internationalization-Related Theories}

The theory of internationalization is a subset of trade theories, which were originated by Smith (1776), who introduced the concept of absolute cost advantage. Then, Ricardo (1817) further developed it into the theory of comparative advantage. Based on these theories, trading across countries in the world was explained as well as the operation of import/export among countries. Companies involved in trading commodities necessary for each country are considered as primary level of internationalization. Later on, the benefits of international trade are further explored by different studies such as gravity model of trade (Isard, 1954), and Heckscher-Ohlin model (Heckscher \& Ohlin, 1991).

Table 1: The field of international business - Activities across the border

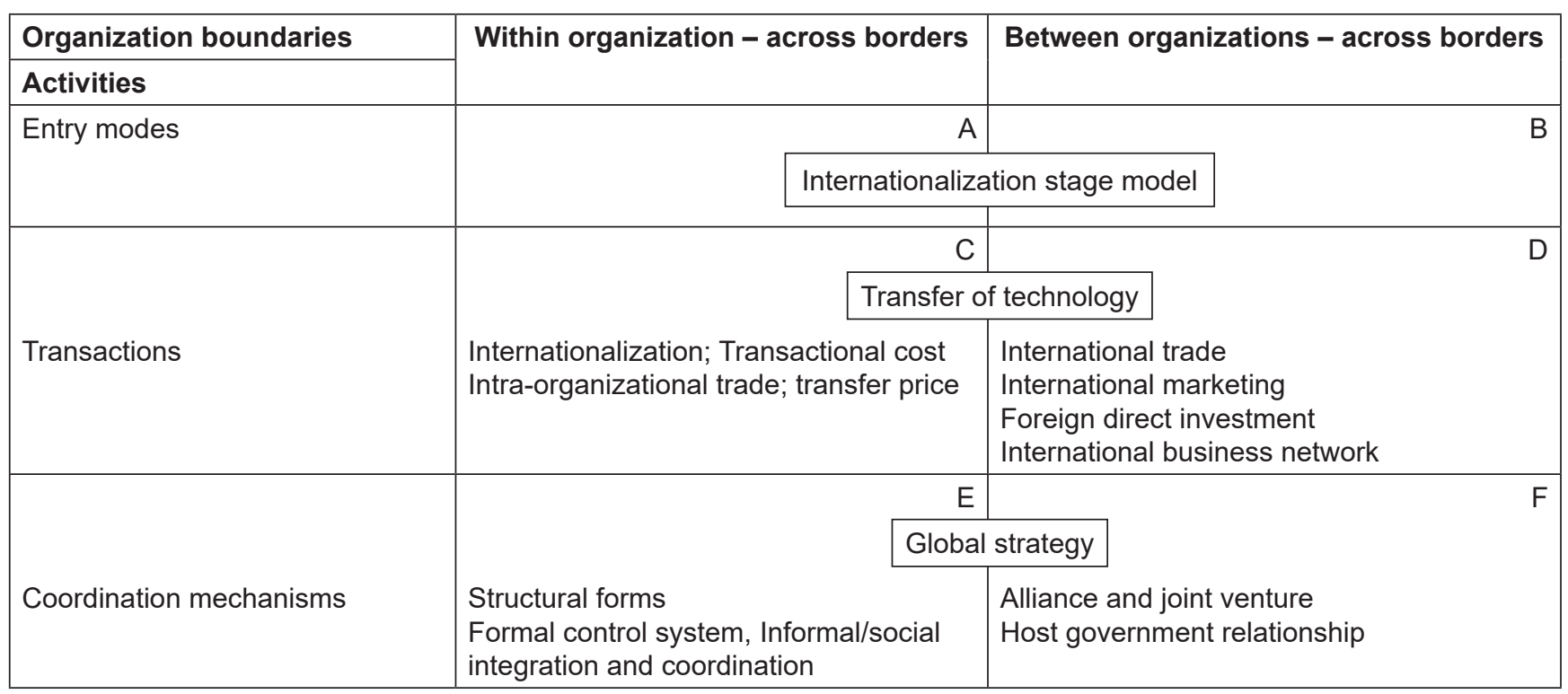

Source: Melin (1992) 
In the $20^{\text {th }}$ century, different models of internationalization were conceptualized such as business alliance, joint ventures, foreign direct investment, international technology transfer, and international processing cooperation. Internationalization can happen within multinational companies (MNCs) or between organizations. Melin (1992) summarized different stages of internationalization shown in Table 1. One of the main characteristics of internationalization is that it happens across national borders either inside or between organizations. Thanks to intraorganization trade, companies can obtain many benefits such as diversification, exploiting local advantages, expanding their markets/customers, optimizing their operation and profits for the whole organizations.

Lyles (1990) and Bettis (1991) concluded that internationalization is a strategic process, which is considered as one of most important research strands. By using the surveyed results from many strategy research scholars, Lyles (1990) arrived at the conclusion that the research on company's internationalization is widely perceived as one of the most important strand of strategic management research. This research also suggested that company manager and CEOs should give priorities to their company's internationalization in the coming decades as internationalization could prepare their company to successfully operate in a globally competitive environment (Bettis, 1991). Thanks to global competition, companies would gain experience and thus effectively compete in medium and long-term. Welch and Luostarinen (1988) suggest a different view according to which internationalization is the process of increasing business operations across the borders, and this should be considered as the strategy process of companies; if they have developed well in the local market, they will move to the next stage, which is expanding to overseas markets. In another view, researchers concluded that internationalization is a natural stage of firm growth. Except for the special type of companies born global, which exported their products/ services from the start, the first target of many companies is to gain a significant domestic market share before exporting as the next and then setting-up representative/ joint venture/subsidiaries in oversea markets. These above arguments are based on the model of product life-cycle by Vernon (1966) and the internationalization process model by Johanson and Vahlne (1977) as the Uppsala model. Another model of internationalization is the innovationrelated internationalization model, which considers internationalization as an innovation process of the firm. This innovation model of internationalization originated from the work by Rogers (1962) and latter further developed by Andersen (1993).

These models above could explain the practical internationalization process, however, they did not answer the question as to how or why firms go international. In addition, Bell (1995) posits that an established chain built from the Uppsala model does not reflect the factors affecting the company's internationalization. Yip et al. (2000) concluded that the Uppsala model did not cover the firmspecific motivation for internationalization. For example, why do companies export from the start instead of building a domestic market share first? Oviatt and McDougall (1994) challenges the Uppsala model by introducing the theory of born global companies, which export their products in international market as soon as they are established.

The comments on the Uppsala model or so-called stage model of internationalization have raised the need to better understand the specific factors that affect internationalization process of the companies in general or specifically the success factors of large companies' internationalization in specific market such as Vietnam where the transition process is undergoing.

\subsection{Factors Affecting Internationalization Process of Large Companies}

Research on factors affecting internationalization process is developed for two types of companies: SME/ small born-global companies; multinational companies (MNCs). For SMEs, Javalgi et al. (2003) used surveyed data of 228 firms to identify key factors affecting internationalization process such as firm size, location and market characteristics. By combining the research from Hutchinson et al. (2005), Ghauri and Cateora (2010), the general framework of success factors affecting internationalization can be created, including three groups of factors: (1) factors related to firms' specific characteristics; (2) factors related to characteristics of the owner/CEO; and (3) factors related to general business environment in which the firm operates.

The measurement of the degree of internationalization as dependent variable is also an important topic. According to Sullivan (1994), it can be measured by the number of top manager's years of experience in the international environment out of his/her total working experience, the number of subsidiaries in overseas countries as a proportion of total number of subsidiaries. For SMEs in Vietnam, Thai and Chong (2008) studied SMEs and discovered the main drivers of internationalization of these companies, especially the factors affecting born-global firms. The study results showed that the entrepreneurs' leadership together with the expectation for short-term profits are main drivers. These firms will have different strategies in selecting internationalization mode depending on market conditions. In addition, it also depends on the internationalization degree of the industry sectors in which the firms operate. 


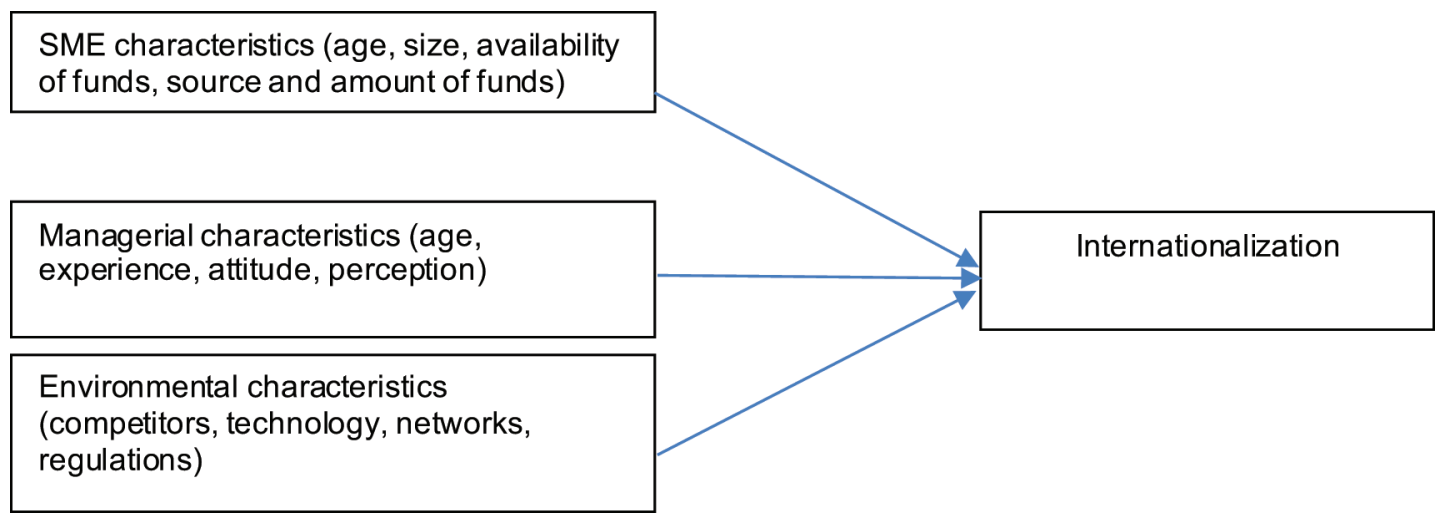

Figure 1: Critical Success factor model of internationalization for SME

Source: Hutchinson, Quinn, and Alexander (2005); Ghauri and Cateora (2010)

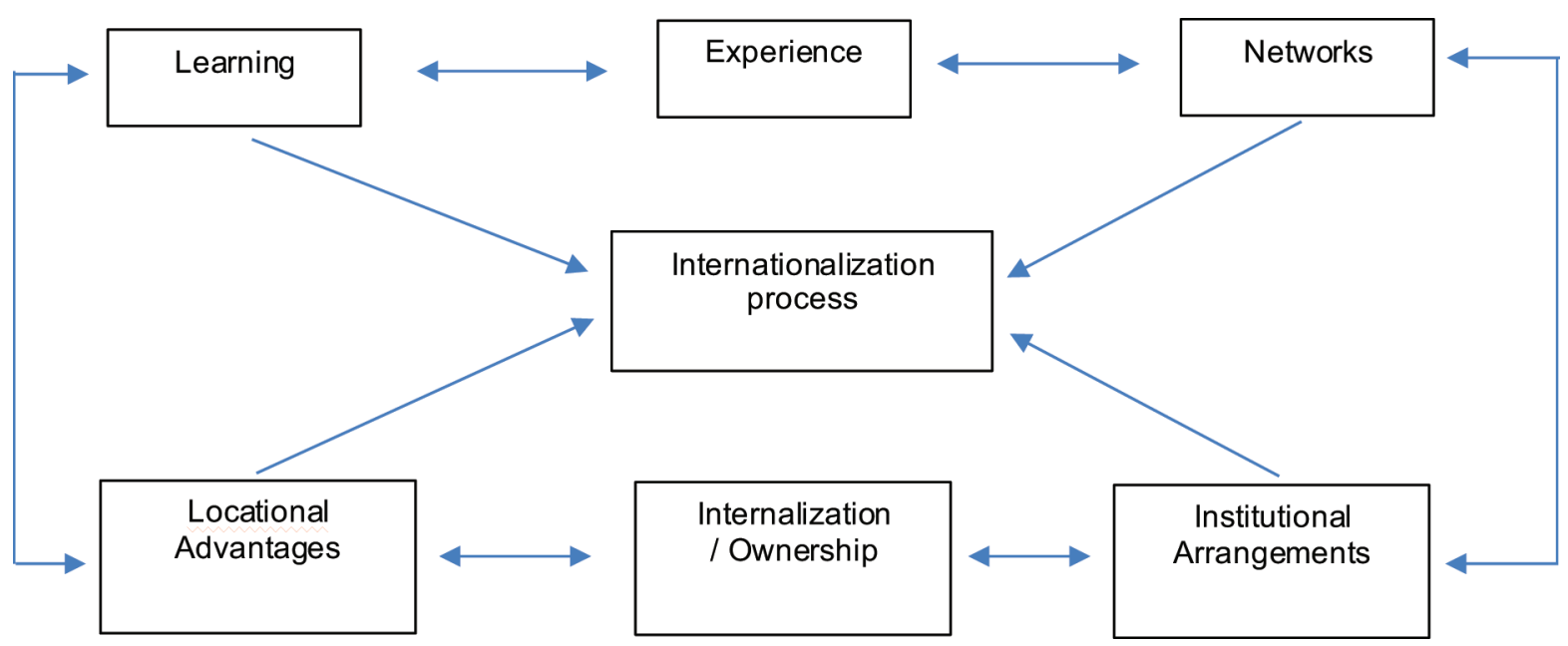

Figure 2: Factors affecting internationalization process of MNCs Source: Amal, Awuah, Raboch, and Andersson (2013)

In another research strand, factors affecting internationalization process of large companies as multinational companies (MNC) are popular and they are normally associated with foreign direct investment as MNCs prefers to develop their own overseas subsidiaries (as foreign direct investment - FDI) to expand their market as one of important stage in their internationalization. Thank to FDI, MNCs become key players in their field. Therefore, local factors of host countries to receive FDI become important such as education and skill level of the local labor force, FDI related regulations, location, and infrastructure development level. For the MNCs from developed countries, research and development (R\&D) is one of the typical factors to secure quality for MNC's products and, thus, enabling them to have long-term competitiveness (Thanasuta et al., 2009). However, R\&D of MNCs from newly-industrialized countries is not strong as that of MNCs in developed countries, making their success factors of internationalization by FDI into developing countries different (Filatotchev et al., 2007). Therefore, different success factors can exist in the internationalization process of MNCs in emerging countries. Amal et al. (2013) made the comparison between emerging MNCs and MNCs from developed countries to find the differences and similarities in their internationalization process. As Figure 2 shows, internationalization process of emerging MNCs are affected by different factors and these factors have a direct influence on and interactions with each other to produce combined effects on internationalization process.

In current literature, the internationalization process of MNCs from developed countries and their success factors is well discussed, however, there is dearth of relevant literature on MNCs and/or large companies from transition economies as Vietnam. In addition, current literature on related topic 
mainly focuses on internationalization of companies from developed countries, while there is little research in the opposite direction, especially as regards the transition economies. Therefore, this paper is designed to fill such the gap.

\section{Research Method and Data Collection}

This research applies the qualitative method with an exploratory nature as it is aimed to discover new factors, particular related to emerging MNCs in a transition economy like Vietnam. In addition, qualitative method could allow deeper cross-cultural understanding as suggested by Marschan-Piekkari and Welch (2004). Furthermore, due to the paucity of studies on internationalization of large companies in transition economies, Eisenhardt (1989) suggested that qualitative method could be a suitable tool. Qualitative research by in-depth interview would allow the exploration of new success factors of internationalization process of large companies in the Vietnamese business context. In a small transition economy, there are few companies in Vietnam deeply involved in internationalization, so we select a single case study of a coffee production company that has a long experience in international markets in order to explore their success factors of internationalization via in-depth interview with different functional managers/experts.

To secure the quality of in-depth interview, this paper will follow the strict process of qualitative research design as well as suggestions from Lincoln and Guba (1985);
Kvale (1995). Steps of in-depth interview designed based on Seidman (2013); Okoli and Pawlowski (2004), will be summarized as below:

Firstly, we choose the case study of a highly internationalized company, described in Box 1, covering by several criteria such as revenue from overseas market, number of international markets where their product name is appeared, etc. Due to the small size of economy as well as the historical reasons the economy is changing from centrally-planned to market-oriented one, there are few large companies having a successful presence in the international market, so the single case study is the best choice. Secondly, we select and create the list of experts/managers involved in international market such as marketing, sale, strategy, product development, etc. Then, we send the email suggesting indepth interview.

Through the literature review, we build up a list of key success factors affecting internationalization process as materials for discussion with experts. During the interview, each expert will be asked to follow the below step:

(1) Explaining to experts the name (in both English and Vietnamese) and meaning of each factor in the list of CSFs in both English and Vietnamese, and requesting comments from them in both names in Vietnamese and the meaning of each factor. Through this step, the name of each factor in Vietnamese will be standardized.

(2) Experts are suggested to comment on the existence of each factor in Vietnam context, and factors perceived by expects to be irrelevant will be deleted.

\section{Box 1: Description of Selected Company as Single Case study}

Vietnam has opened the economy since 1986 to the world of capitalism, firstly by allowing foreign investors to invest in Vietnam and then allowing domestic private sectors to be established and operated since the early 1990s. Coffee Company A, a coffee production and export company, has been operating in the coffee industry since the early of 1990 as a family company specialized in roasting/grinding of coffee bean and selling directly to cafeteria without brand name. At that time, there were many small family coffee companies without their own brand names, except only one state-owned coffee company with the brand name Vinacafe. In addition, the export right was not granted to private company. Coffee Company A has decided to build its own name in instant coffee production, selling in the domestic market. In addition, it has franchised its own brand name to establish a number of café retail shop in big cities of Vietnam. Thank to this strategy, high quality product and growing high-income consumers, it has become quite successfully in the home market.

Due to the restricted permission of exports/import for the private sector, until the end of 1990, the company planned to go internationally by itself (Dana, 1994) when the Government of Vietnam allowed private company to export directly, supporting them to go internationally since 2003. So far, Coffee Company A has already become one of only a handful of Vietnamese brands that have gained international recognition, exporting to more than 60 countries in the world under their own name. It also has proposed to the Vietnamese government a strategy to develop a National Coffee Industry. The strategy has three main objectives: prosperity, sustainability, and national character. The company projects that the coffee industry could create 5-6 million jobs and grow to become a US $\$ 20$ billion annual business over the next 15 years. Its coffee brand has already firmly established itself at home. According to a survey of brands by B\&C Company and Nikkei BP Consultancy in Vietnam, Coffee Company A was voted one of Vietnam's most popular brands, alongside Apple, Google, and Nokia by 2011. By the year 2014, it has franchised more than 1000 café shops across Vietnam and several ones abroad. CEO of the company showed his strong determination to go abroad by famous saying that: "The fine taste of Vietnamese coffee and the right strategies will allow us to conquer the world". 
(3) Experts will be free to add new success factors of internationalization process of their company. In addition, they are also requested to explain in details these new factors.

(4) Finally, the experts will rank these factors as they perceive them based on impact level of each factor on internationalization process of their company.

After each interview, the summarized content of interview will be sent to correspondent interviewee for their comments/revisions to ensure there is no discrepancies or misunderstandings between interviewer and interviewee. In addition, the list of factors will be updated for the next interview stage.

\section{Results and Discussion}

After five rounds of individual interviews with five experts, we decided to stop the individual interviews because it seems that the information become redundant. Table 2 lists the confirmed factors obtained from the interviews.

From the above list, we could divide the factors into three groups based on their strategic levels, including: (1) factors related to corporate strategy such as factor 1 and 2; (2) factors related to external business environment such as factor 3, 4; (3) factors related to functional strategy of the company such as factor 5, 6; and (4) factors related to internal environment of the company as factor 7 . We may propose the general framework for success factors of internationalization as below in which each group of factors having the same characteristic based on its strategic level to the company.

The group of factors related to corporate strategy has showed several interesting insights of corporate governance. Lack of long time and consistent agreement among the management board, the CEO could not plan in the long range for internationalization, as well as mobilization of necessary resources and capable staffs. In addition, the good relationship between CEO and the management board is also quite important, particularly with the Chairman (Kakabadse et al., 2006) to help CEO for better communication, strong commitment and supports. CEO should make sure there is a strong, consistent and long-term supports from the management board for internationalization.

Table 2: Key success factors affecting internationalization process of large Vietnamese companies

\begin{tabular}{|l|l|c|}
\hline Order No. & \multicolumn{1}{|c|}{ Key Factors } & Frequency \\
\hline 1 & Determination of CEO/Management board & $5 / 5$ \\
\hline 2 & Internationalization strategy & $5 / 5$ \\
\hline 3 & Relationship between two countries & $5 / 5$ \\
\hline 4 & $\begin{array}{l}\text { Incentive policies from the Government for internationalization (export policies, exchange } \\
\text { rate, international payment, etc) }\end{array}$ & $4 / 5$ \\
\hline 5 & Selecting agent/partners/wholesalers in oversea market & $4 / 5$ \\
\hline 6 & Pricing strategy & $4 / 5$ \\
\hline 7 & Selecting capable staff for international works & $4 / 5$ \\
\hline
\end{tabular}

(1) Factors relating to corporate strategy

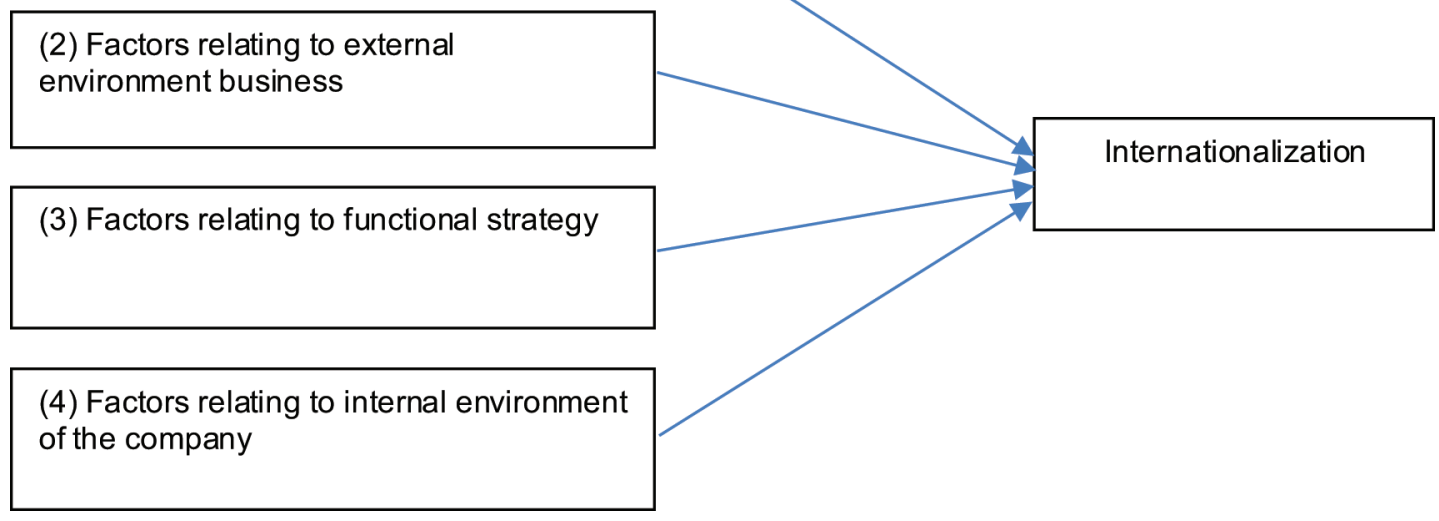

Figure 3: Proposed general framework for success factor model of internationalization process of large company 
The second group of factors related to external environment seems to be out of company's control as it is purely in government's hands. As to the reason why the company has not done well in markets with which Vietnam has a long-time relationship since the Cold War, such as Russia and some countries in Eastern Europe, the interviewee advised that it is because of low secured payment between two countries and, thus, it is quite risky to enter such markets. Policy-related factors are also in this group such as export restriction policy, on which Vietnam could be a typical example as the government allows only state-owned companies to operate export/import right until the end of 1990. Therefore, it was difficult for private companies to go internationally under their own brand name. They only export their products as processing one under the name of importers/distributors in another market, thus, limiting their willingness to take advantage on internationalization. As the case of Coffee Company A in Vietnam, when they obtained the right to export directly under their own brand name, their revenue from oversea market increased significantly. In addition, they have taken more proactive actions to consolidate their brand in overseas markets and, thus, support their sale better as they do not depend on intermediary company acting as exporter only.

The third group of factors is related to functional strategies of companies such as pricing strategy and agent selection in specific foreign markets. These factors are likely to be correlated thanks to good agent, the company will understand the market and target customers' behavior and then, they could develop the most suitable pricing strategy, which are very crucial for sale. Moreover, good agent understands well the taste and behavior of target consumers and, thus, advises the coffee company to make necessary modification in product formula to generate a unique taste, which is crucial in the coffee industry. In the case study, the coffee company has found the Vietnamese overseas who have rich knowledge of cultural consumption of target market together with preference tastes of people and, thus, able to advise the company for product to be better suited to consumer's preference.

The final group of factors in this paper is related to the internal environment of the company referring to internal management work to select the capable staff for internationalization work. It is quite clear that entering new markets is very challenging and, thus, the company needs to choose the capable staff who can work independently in innovative manners to cope with fast-moving developments in international market, as interviewee revealed. The factor of capable staff in internationalization is similar to findings by Sanyal et al. (2020b) that human capital is an important factor for SMEs in developing countries to expand internationally. As per interview results, these staff must understand common business practices of both Vietnam and target countries/markets as well as cultural differences in consumption of export products so that they produce better and constant sales in overseas countries.

Thank to this general framework, newly-founded success factors can be easily located in the specific group, and allow (1) to explain the interaction among factors within one group; and (2) to describe the relationship of each factor on the internationalization in systematic manner rather than individually.

\section{Conclusions and Limitations of the Research}

\subsection{Conclusions}

Internationalization is a must for large companies in developing countries as the domestic market has limited size. Thanks to internationalization, large companies can gain better price/revenue/benefit from overseas markets. In addition, their internationalized activities will consolidate their domestic market as they can learn from international customers for both domestic and international market expansion. Furthermore, by having certain position in international market, the company can update production technology at the international level, which will secure their competitiveness in the long run. In the long-range planning, thanks to internationalization, they may have a chance to look for strategic alliances with international partners to archive economies of scale to secure the long-run competitiveness. In another aspect of supporting business, the company may develop its business in the horizontal expansion to invest in the new business, which is supportive of its core business. Therefore, internationalization is quite important to medium and large company.

Through the identified factors based on interviews, some managerial advices for managers can be offered. Firstly, in order to implement the internationalization process successfully, the management board and CEO must have deep agreement and strong determination to go internationally as this internationalization process is complex and time consuming. In addition, the investment costs are high as are efforts of the firm in the period prior to gaining the revenue/profit and, thus, a strong agreement among management board and CEO will secure necessary resources for success. Secondly, such a determination must be operationalized through a suitable internationalization strategy, which should be based on a relationship between two countries as Vietnam is still a newcomer in the world market. Finally, the use of qualified staff for international jobs and selecting the right overseas agents are important factors to successfully implement an internationalization strategy. 
As for policymakers, it should be noted that domestic market is considered as first stage of internationalization and, thus, policies should be designed to support these companies in both domestic and international markets. In addition, payment insurance policies and/or international secured-agreement payment should be developed with prospective markets to support domestic companies to internationalization.

\subsection{Limitations and Further Research}

Due to the small number of case study and experts for related to a single company operating in consumer products, it could be difficult to generalize the research results. However, it provides specific factors affecting internationalization of large companies in Vietnam for consumer products. In order to have success factors, which can be generalized, it is necessary to develop further in-depth interviews in different companies of various industries to gain a wide range of data/information for improving the proposed framework of success factors. In addition, it is suggested that further study of this topic should be started by qualitative study of in-depth interview to explore more success factors. Then, it could be suitable to carry out survey by self-completed questionnaire for econometric analysis such as examining the relationship of each factor and internationalization of large companies in Vietnam. Another direction is that in-depth interviews may be repeated in different time to explore whether or not these CSFs may change in different stages of internationalization. In further study, it could be reasonable to generalize the research results for managerial implication and policy recommendation.

\section{References}

Ali, H., Hao, Y., \& Aijuan, C. (2020). Dynamic Capabilities, Environmental Dynamism and Small and Medium Enterprises' Internationalization Level. Journal of Asian Finance, Economics and Business, 7(9), 527-536. https://doi. org/10.13106/jafeb.2020.vol7.no9.527

Amal, M., Awuah, G. B., Raboch, H., \& Andersson, S. (2013). Differences and similarities of the internationalization processes of multinational companies from developed and emerging countries. European Business Review, 25(5), 411-428. https:// doi.org/10.1108/EBR-08-2012-0048

Andersen, O. (1993). On the internationalization process of firms: A critical analysis. Journal of International Business Studies, 24(2), 209-231.

Bell, J. (1995). The internationalization of small computer software firms. European Journal of Marketing, 38(9-10), 1236-1251.

Bettis, R. A. (1991). Strategic management and the straightjacket: An editorial essay. Organization Science, 2(3), 315-319.
Dana, L. P. (1994). A Marxist mini-dragon? Entrepreneurship in today's Vietnam. Journal of Small Business Management, 32(2), 95.

Eisenhardt, K. M. (1989). Building theories from case study research. Academy of Management Review, 14(4), 532-550.

Filatotchev, I., Strange, R., Piesse, J., \& Lien, Y. C. (2007). FDI by firms from newly industrialised economies in emerging markets: corporate governance, entry mode and location. Journal of International Business Studies, 38(4), 556-572.

Ghauri, P. N. \& Cateora, P. (2010). International Marketing ( $3^{\text {rd }}$ ed.). London, UK: McGraw Hill Education.

Heckscher, E. F., \& Ohlin, B. G. (1991). Heckscher-Ohlin trade theory. Cambridge, MA: The MIT Press.

Hutchinson, K., Quinn, B., \& Alexander, N. (2005). The internationalisation of small to medium-sized retail companies: towards a conceptual framework. Journal of Marketing Management, 21(1-2), 149-179.

Isard, W. (1954). Location Theory and Trade Theory: Short-Run Analysis. The Quarterly Journal of Economics, 68(2), 305320. https://doi.org/10.2307/1884452

Javalgi, R. R. G., Griffith, D. A., \& Steven White, D. (2003). An empirical examination of factors influencing the internationalization of service firms. Journal of Services Marketing, 17(2), 185-201. https://doi. org/10.1108/08876040310467934

Johanson, J., \& Vahlne, J. E. (1977). The internationalization process of the firm - a model of knowledge development and increasing foreign market commitments. Journal of International Business Studies, 8(1), 23-32.

Kakabadse, A., Kakabadse, N. K., \& Barratt, R. (2006). Chairman and chief executive officer (CEO): that sacred and secret relationship. Journal of Management Development, 25(2), 134-150. https://doi.org/10.1108/02621710610645126

Kokko, A., \& Sjöholm, F. (2004). The Internationalization of Vietnamese SMEs. EIJS Working Paper Series 193, Stockholm School of Economics, The European Institute of Japanese Studies.

Kvale, S. (1995). The social construction of validity. Qualitative Inquiry, 1(1), 19-40.

Lincoln, Y., \& Guba, E. (1985). Naturalistic Inquiry (Vol. 75). Beverly Hills, CA: Sage Publications.

Lyles, M. A. (1990). A research agenda for strategic management in the 1990s. Journal of Management Studies, 27(4), 363-375.

Marschan-Piekkari, R., \& Welch, C. (Eds.). (2004). Qualitative research methods in international business: The state of the art. Handbook of qualitative research methods for international business (5-24). Cheltenham, UK: Edward Elgar.

Melin, L. (1992). Internationalization as a strategy process. Strategic Management Journal, 13(S2), 99-118. 
Okoli, C., \& Pawlowski, S. D. (2004). The Delphi method as a research tool: an example, design considerations and applications. Information \& Management, 42(1), 15-29.

Oviatt, B. M., \& McDougall, P. P. (1994). Toward a theory of international new ventures. Journal of International Business Studies, 25(1), 45-64.

Ricardo, D. (1817). On the Principles of Political Economy and Taxation. London, UK: George Bell and Sons.

Rogers, E. M. (1962). Diffusion of innovations (1st ed.). New York: Free Press of Glencoe

Sanyal, S., Hisam, M. W., \& Baawain, A. M. S. (2020a). Challenges Facing Internationalization of SMEs in Emerging Economies: A Study on OECD Model. Journal of Asian Finance, Economics, and Business, 7(2), 281-289. https://doi.org/10.13106/ jafeb.2020.vol7.no2.281

Sanyal, S., Hisam, M. W., \& Baawain, A. M. S. (2020b). Entrepreneurial Orientation, Network Competence and Human Capital: The Internationalization of SMEs in Oman. The Journal of Asian Finance, Economics and Business, 7(8), 473483. https://doi.org/10.13106/jafeb.2020.vol7.no8.473

Seidman, I. (2013). Interviewing as qualitative research: A guide for researchers in education and the social sciences. New York, NY: Teachers College Press.
Smith, A. (1776). The Wealth of Nations. Oxford, UK: Oxford University Press.

Sullivan, D. (1994). Measuring the degree of internationalization of a firm. Journal of International Business Studies, 25(2), 325342.

Thai, M. T. T., \& Chong, L. C. (2008). Born-global: The case of four Vietnamese SMEs. Journal of International Entrepreneurship, 6(2), 72.

Thanasuta, K., Patoomsuwan, T., Chaimahawong, V., \& Chiaravutthi, Y. (2009). Brand and country of origin valuations of automobiles. Asia Pacific Journal of Marketing and Logistics, 21(3), 355-375.

Vernon, R. (1992). International investment and international trade in the product cycle. In: International economic policies and their theoretical foundations (pp. 415-435). New York, NY: Academic Press.

Welch, L. S., \& Luostarinen, R. (1988). Internationalization: Evolution of a concept. Journal of General Management, 14(2), 34-55.

Yip, G. S., Biscarri, J. G., \& Monti, J. A. (2000). The role of the internationalization process in the performance of newly internationalizing firms. Journal of International Marketing, 8(3), 10-35. 